\title{
Aplikasi Ergonomi untuk Meningkatkan Produktivitas Pengrajin Kayu Bekas (Drifwoods) di Kabupaten Badung, Bali
}

\author{
I Gede Nyoman Suta Waisnawa ${ }^{1}$, I Made Sudana ${ }^{2}$, Ida Bagus Swaputra ${ }^{3}$ \\ ${ }^{1,2}$ JurusanTeknik Mesin, Politeknik Negeri Bali \\ ${ }^{3}$ Jurusan Manajemen, STIMI Handayani Denpasar
}

\begin{abstract}
The results of the implementation of ergonomics in deco and shop camps were specifically focused on improving work facilities, workplaces, layouts, work procedures, and work environment, increasing workers' comfort in conducting production activities, and utilizing space so that the production process becomes safe and flexible. Outputs that have been achieved included (1) workstations arranged in an efficient material flow layout supported by adequate work tools so it can optimize the achievement of production targets, (2) improvement of the process and procedures for completing work, (3) improvement and savings in the use of materials, machinery/tools, and humans, (4) utilization of humans' efforts, (5) improving workspace arrangements that can provide a comfortable and safe working environment. The implementation of participatory ergonomics production capacity can reach 456 pieces/year and shop production as many as 24 pieces/year, for example; tiger, bear, eagle, cow head etc. After the ergonomic intervention, the production capacity increased to 52 pieces/year. The impact of this program was an increase in production capacity of Ari deco craftsmen (67.5\%) and Kubu shop craftsmen (46.15\%), while business partners' turnover was around $69.9 \%$.
\end{abstract}

Keywords: ergonomics, productivity, craftsmen

\section{PENDAHULUAN}

Pesatnya pertumbuhan UKM dibidang kerajinan (Driftwood) ternyata tidak diikuti dengan peningkatan kualitas, kuantitas serta pengetahuan di bidang teknologi dan manajemen dari pengelola usaha kerajinan tersebut. Pertumbuhan usaha kerajinan yang tergolong UMK di kabupaten Badung jumlahnya telah mencapai 1.231 unit usaha. Jumlah tenaga kerja yang terlibat sebanyak 12.230 orang, dengan jumlah investasi mencapai Rp. 47,920 M serta nilai produksi mencapai Rp. 205,200 M (Disperindag-Badung, 2013).

Sistem kerja adalah suatu ilmu terdiri dari teknik-teknik dan prinsip-prinsip untuk mendapatkan rancangan terbaik dari sistem kerja yang bersangkutan. Teknik-teknik dan prinsip-prinsip ini digunakan untuk mengatur komponen-komponen sistem kerja yang terdiri dari manusia dengan sifat dan kemampuannya, peralatan kerja, bahan serta lingkungan kerja sedemikian rupa sehingga dicapai tingkat efektifitas dan efisiensi yang tinggi bagi perusahaan serta aman, sehat dan nyaman bagi pekerja (Sutalaksana, 2006).
Analisis sistem kerja pada UKM Ari Deco dan Kubu Shop dikhususkan pada perbaikan sistem kerja dan aliran material serta pengelompokan proses yang dapat meminimasi waktu perpindahan, meningkatkan kenyamanan pekerja dalam melakukan kegiatan produksi, pemanfaatan ruang sehingga proses produksi menjadi aman dan fleksibel. Setelah dilakukan analisis sistem kerja diharapkan dapat mengurangi permasalahan yang terdapat pada UKM Ari Deco dan Kubu Shop.

Ari Deco dan Kubu Shop adalah usaha kerajinan (Driftwood) berbahan baku limbah kayu pantai dan potongan kayu bekas. Kubu Shop berada di jalan Tangkuban Perahu, Kecamatan Kuta Tengah, Kabupaten Badung, Bali. Ari Deco berada di Desa Abiansemal Kecamatan Abiansemal terletak lebih kurang $10 \mathrm{~km}$ arah utara kabupaten Badung. Di daerah ini banyak berkembang usaha kerajinan (Driftwood) yang menghasilkan produk berupa souvenir yang sebagian besar berbahan baku limbah kayu pantai dengan produk berupa berbagai ornamen seni dan antik yang berupa aneka patung binatang, meja rias, kursi, almari, tempat cermin, tempat lampu dan lainnya. 
Pendekatan ergonomi yang diaplikasikan di pengrajin diantaranya: 1)Perancangan, modifikasi, penggantian/ perbaikan fasilitas kerja untuk meningkatkan produktivitas, kualitas produk dan lingkungan kerja fisik. 2) Perancangan, modifikasi area dan tempat kerja, tata-letak (layout) fasilitas produksi untuk memudahkan dan mempercepatkan operasi kerja, material handling, service dan maintenance, 3) Perancangan dan modifikasi tatacara kerja (work methods), termasuk dalam hal ini mekanisasi/otomasi proses dan alokasi beban kerja dalam sebuah sistem manusia-mesin, 4) Perencanaan kondisi lingkungan fisik kerja yang mampu memberikan kenyamanan, keamanan/keselamatan dan kesehatan kerja bagi manusia-operator (temperatur, noise, pencahayaan, vibrasi, dan lainlain) untuk meningkatkan motivasi kerja, kualitas lingkungan kerja dan produktivitas.

Proses pengerjaan produk kerajinan berbahan baku limbah kayu pantai ini sebagian besar menggunakan proses kerja tangan secara manual. Tahapan prosesnya meliputi: penandaan pola pada papan atau kayu, pemotongan, pembentukan sesuai desain pesanan, perakitan dengan paku tembak, pembersihan dengan angin, pengeringan dan pengemasan. Kondisi stasiun kerja dan tata letak fasilitas saat ini tidak beraturan sehingga aliran bahan/material tidak efisien. Pemanfaatan luas area kerja belum dilaksanakan dengan baik sesuai dengan standar kelayakan kerja dimana proses kerja kerajinan ini sebagian besar menggunakan perkakas dengan risiko bahaya kecelakaan yang relatif tinggi seperti paku tembak yang sangat berbahaya. Pemotongan limbah kayu pantai masih dilakukan diruangan yang terbuka sehingga mencemari udara dilingkungan sekitarnya.

Permasalahan yang di hadapi ke dua mitra Ari Deco dan Kubu Shop sebagai berikut:

a. Tata letak peralatan kerja yang masih kurang baik dimana hanya diletakkan di atas lantai sehingga memiliki jarak yang tidak pasti dan jarak yang masih terlalu jauh serta kebiasaan pengrajin meletakkan peralatan tidak pada tempatnya semula.

b. Minimnya penggunaan peralatan dan aliran material. c. Adanya gerakan kerja pengrajin yang cenderung kurang efisien, sehingga menyebabkan waktu proses menjadi lama.

d. Kondisi stasiun kerja saat ini tidak beraturan sehingga aliran bahan/material tidak efisien. Faktor keselamatan kerja belum dilaksanakan dengan baik sesuai dengan standar kelayakan kerja dimana proses kerja kerajinan ini sebagian besar menggunakan perkakas dengan risiko bahaya kecelakaan yang relatif tinggi seperti kena setrum listrik dimana instalasi listrik belum terpasang dengan baik dan aman sesuai standar, pengeringan dan pengemasan.

e. Proses produksi kerajinan masih menggunakan perkakas yang manual dengan jumlah yang terbatas seperti: kampak tangan untuk membelah potongan kayu, bor tangan, palu dan gergaji potong manual. Pemenuhan target penyelesaian produk pesanan menjadi terkendala karena produktivitas dan waktu proses relatif lama.

\section{METODE PELAKSANAAN}

A. Solusi yang Ditawarkan

1. Perencanaan dan perbaikan fasilitas kerja untuk meningkatkan kenyamanan pengrajin saat bekerja. Fasilitas kerja yang dirancang berupa landasan kerja, meja kerja, kursi kerja khusus untuk Kubu Shop, dan mesin pembelah kayu.

2. Perencanaan dan perbaikan tempat kerja ditinjau dari sudut pandang produksi adalah susunan fasilitas-fasilitas produksi untuk memperoleh efisiensi pada suatu produksi. Perancangan tata letak meliputi pengaturan tata letak fasilitas operasi dengan memanfaatkan area yang tersedia untuk penempatan mesinmesin, bahan-bahan, perlengkapan untuk operasi, personalia, dan semua peralatan serta fasilitas yang digunakan dalam proses produksi (Purnomo, 2004).

3. Perencanan dan modifikasi work methods yaitu digunakan untuk mengatur komponenkomponen sistem kerja yang terdiri dari manusia dengan sifat dan kemampuannya, peralatan kerja, bahan serta lingkungan kerja 
edemikian rupa sehingga dicapai tingkat efektifitas dan efisiensi yang tinggi bagi perusahaan serta aman, sehat dan nyaman bagi pekerja (Sutalaksana, 2006).

4. Peningkatan dan perbaiki lingkungan fisik kerja yaitu semua keadaan berbentuk fisik yang terdapat disekitar tempat kerja dimana dapat mempengaruhi pengrajin baik secara langsung maupun tidak langsung (Sedarmayanti, 2009).

\section{B. Target Luaran}

Program kegiatan IbPE yang dirancang sebagai berikut.

Tabel 1. Kegiatan UKM Ari Deco dan Kubu Shop

\begin{tabular}{|c|c|c|}
\hline \multirow{2}{*}{ Tujuan Kegiatan } & \multicolumn{2}{|c|}{ Bentuk Kegiatan } \\
\hline & Ari Deco & Kubu Shop \\
\hline $\begin{array}{l}\text { Perbaikan dan } \\
\text { penataan stasiun } \\
\text { kerja }\end{array}$ & $\begin{array}{l}\text { Pembuatan layout } \\
\text { Penataan peralatan } \\
\text { kerja yang } \\
\text { ergonomis, } \\
\text { Pembuatan kantor } \\
\text { dan tempat pajang }\end{array}$ & $\begin{array}{l}\text { Pembuatan } \\
\text { layout Penataan } \\
\text { peralatan kerja, } \\
\text { Pembuatan kursi } \\
\text { kerja dan } \\
\text { landasan kerja } \\
\text { yang ergonomis } \\
\text { (berkebutuhan } \\
\text { khusus) }\end{array}$ \\
\hline $\begin{array}{l}\text { Peningkatan } \\
\text { sarana dan fasilitas } \\
\text { produksi }\end{array}$ & $\begin{array}{l}\text { Pengadaan } \\
\text { peralata yang lebih } \\
\text { modern dan } \\
\text { ergonomis, } \\
\text { penataan instalasi } \\
\text { listrik dan } \\
\text { kompresor } \\
\end{array}$ & $\begin{array}{l}\text { Pengadaan } \\
\text { peralatan yang } \\
\text { lebih modern } \\
\text { dan ergonomis, } \\
\text { penataan } \\
\text { instalasi listrik } \\
\text { dan kompresor } \\
\end{array}$ \\
\hline $\begin{array}{l}\text { Peningkatan } \\
\text { keselamatan kerja }\end{array}$ & $\begin{array}{l}\text { Pelatihan K3 dan } \\
\text { penggunaan } \\
\text { peralatan kerja }\end{array}$ & $\begin{array}{l}\text { Pelatihan K3 dan } \\
\text { penggunaan } \\
\text { peralatan kerja }\end{array}$ \\
\hline Sistem Kerja & $\begin{array}{l}\text { Mengurangi } \\
\text { gerakan yang tidak } \\
\text { produktif, } \\
\text { penataan tempat } \\
\text { kerja yang } \\
\text { ergonomis }\end{array}$ & $\begin{array}{l}\text { Mengurangi } \\
\text { gerakan yang } \\
\text { tidak produktif, } \\
\text { penataan tempat } \\
\text { kerja yang } \\
\text { ergonomis }\end{array}$ \\
\hline Aliran Material & $\begin{array}{l}\text { Mengatur aliran } \\
\text { material }\end{array}$ & $\begin{array}{l}\text { Mengatur aliran } \\
\text { material }\end{array}$ \\
\hline
\end{tabular}

\section{HASIL DAN PEMBAHASAN}

\section{A. Hasil}

Perencanaan tata letak fasilitas kerja dan penetapan luas area yang dibutuhkan tata letak pada dasarnya merupakan penempatan dan pengaturan mesin, peralatan produksi, penempatan material, keleluasaan operator bergerak, dan aktivitas lainnya. Kebutuhan luas area ini harus dipertimbangkan untuk seluruh. aktivitas yang ada di dalam usaha tiga macam area yang harus diberikan, yaitu area yang harus diperlukan untuk operasi dari mesin dan peralatan produksi yang ada, area yang diperlukan untuk penyimpanan bahan baku atau benda jadi yang telah selesai dikerjakan, dan area yang diperlukan untuk fasilitas-fasilitas pelayanan. Penetapan kebutuhan luas area yang diperlukan untuk sebuah stasiun kerja yang selanjutnya dipakai untuk melaksanakan suatu aktivitas produksi. Pengaturan tata letak fasilitas dan penetapan luas area produksi Ari Deco dan Kubu Shop dapat dilihat pada Gambar 1 dan 2.

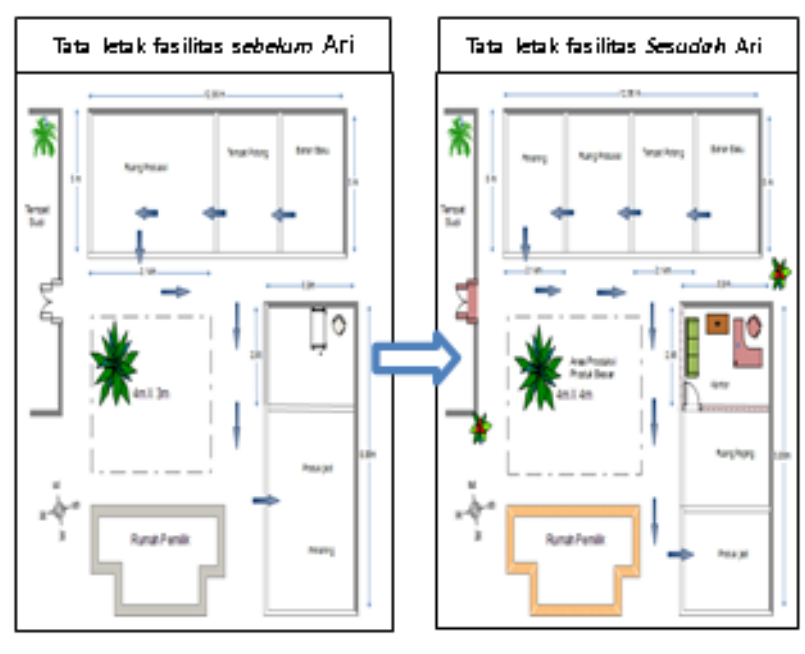

Gambar 1. Lay Out Ari Deco

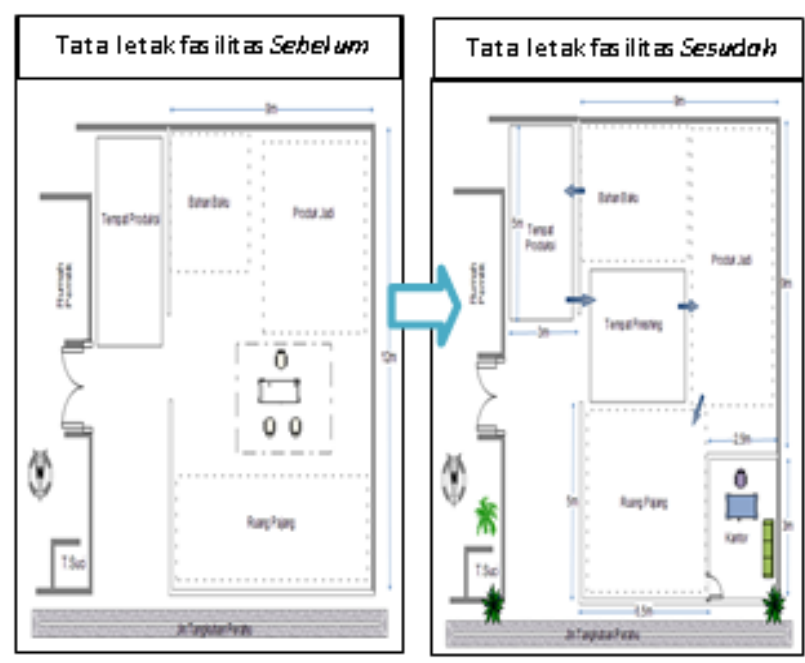

Gambar 2. Lay Out Kubu Shop

Perbaikan metode kerja adalah proses dimana pengrajin dianalisis untuk meningkatkan produktivitas kerja. Analisis dilakukan dengan meng- 
identifikasi metode (methods analysis) yang berlangsung saat ini kemudian merancang dan menerapkan metode kerja yang lebih efektif dan efisien dengan tujuan akhir adalah waktu penyelesaian lebih singkat dan cepat.

Dari beberapa kegiatan Ipteks bagi Produk Ekspor (IbPE) yang telah dilaksanakan pada tahun pertama kedua dan ketiga UKM mitra maka dapat ditampilkan kondisi eksisting UKM sebelum dan sesudah dilakukan pendampingan, seperti pada tabel 2 .

Tabel 2. Sebelum dan sesudah intervensi ergonomi

\begin{tabular}{|c|c|c|}
\hline Uraian & $\begin{array}{c}\text { Ari Deco } \\
\text { (Sebelum) }\end{array}$ & Ari Deco (Sesudah) \\
\hline Bahan baku & $\begin{array}{l}\text { Limbah kayu } \\
\text { pantai hempasan, } \\
\text { kayu kopi, } \\
\text { amplas }\end{array}$ & $\begin{array}{l}\text { Limbah kayu } \\
\text { pantai hempasan, } \\
\text { kayu kopi, amplas, } \\
\text { lem fox dan kaca }\end{array}$ \\
\hline $\begin{array}{l}\text { Peralatan } \\
\text { produksi }\end{array}$ & $\begin{array}{l}\text { Paku } \\
\text { tembak/Ramset } \\
3 \text { unit, kompresor } \\
2 \text { unit, bor tangan } \\
\text { Mesin potong, } \\
\text { kayu portable } 2 \\
\text { unit, gerinda } \\
\text { tangan 1unit, } \\
\text { sirkel 1unit, alat } \\
\text { finishing } \\
\end{array}$ & $\begin{array}{l}\text { Paku tembak/Ramset } \\
5 \text { unit, kompresor } 3 \\
\text { unit, Mesin potong } \\
\text { kayu portable } 3 \text { unit, } \\
\text { gerinda tangan } 2 \text { unit, } \\
\text { sirkel lunit, alat } \\
\text { finishing }\end{array}$ \\
\hline Aliran Material & Tidak beraturan & $\begin{array}{l}\text { Pola aliran bahan } \\
\text { zig-zag }\end{array}$ \\
\hline $\begin{array}{l}\text { Kapasitas } \\
\text { produksi per } \\
\text { hari }\end{array}$ & $\begin{array}{l}\text { 2-5 unit produksi } \\
\text { /minggu }\end{array}$ & $\begin{array}{l}\text { 5-8 unit produksi } \\
\text { /minggu }\end{array}$ \\
\hline Jumlah Produk & 308 Produk/Tahun & 456 produk/tahun \\
\hline Uraian & $\begin{array}{c}\text { Kubu Shop } \\
\text { (Sebelum) }\end{array}$ & $\begin{array}{c}\text { Kubu Shop } \\
\text { (Sesudah) }\end{array}$ \\
\hline Bahan baku & $\begin{array}{l}\text { Limbah kayu atau } \\
\text { potongan kayu sisa } \\
\text { dari } \\
\text { industri mebel, } \\
\text { amplas }\end{array}$ & $\begin{array}{l}\text { Limbah kayu atau } \\
\text { potongan kayu sisa } \\
\text { dari industri mebel, } \\
\text { amplas }\end{array}$ \\
\hline $\begin{array}{l}\text { Perlatan } \\
\text { produksi }\end{array}$ & $\begin{array}{l}\text { Paku } \\
\text { tembak/Ramset } \\
1 \text { unit, Mesin } \\
\text { potong kayu } \\
\text { portable } 1 \text { unit, } \\
\text { Bor tangan 1 unit, } \\
\text { sirkel 1unit, alat } \\
\text { finishing } \\
\end{array}$ & $\begin{array}{l}\text { Paku tembak/Ramset } \\
2 \text { unit, kompresor } 1 \\
\text { unit, Mesin potong } \\
\text { kayu portable } 2 \text { unit, } \\
\text { Bor tangan tangan } 2 \\
\text { unit, sirkel } 2 \text { unit, alat } \\
\text { finishing }\end{array}$ \\
\hline $\begin{array}{l}\text { Aliran } \\
\text { Material }\end{array}$ & Tidak beraturan & $\begin{array}{l}\text { Pola aliran bahan } \\
\text { zig-zag }\end{array}$ \\
\hline $\begin{array}{l}\text { Kapasitas } \\
\text { produksi per } \\
\text { hari }\end{array}$ & $\begin{array}{l}1 \text { unit } \\
\text { produksi/bulan }\end{array}$ & $\begin{array}{l}2 \text { unit produksi } \\
\text { /minggu }\end{array}$ \\
\hline $\begin{array}{l}\text { Jumlah } \\
\text { Produk }\end{array}$ & 24 Produk/tahun & 52 Produk/tahun \\
\hline
\end{tabular}

Produktifitas Kerja, Setelah dilakukan penerapan ergonomi partisipatori produktifitas pekerja juga meningkat karena sebelumnya produk yang dihasilkan oleh pengrajin Ari Deco sebanyak 308 buah/tahun dengan berbagai macam produk misal kap lampu, pigura cermin, meja makan, dll. Setelah dilakukan penerapan ergonomi partisipatori kapasitas produksi. Gambar 3 kursi dan landasan kerja dapat mencapai 456 buah/tahun dan produksi Kubu shop sebanyak 24 buah/tahun misal binatang harimau, beruang, garuda, kepala sapi dll setelah dilakukan intervensi ergonomi meningkat menjadi 52 buah/tahun.

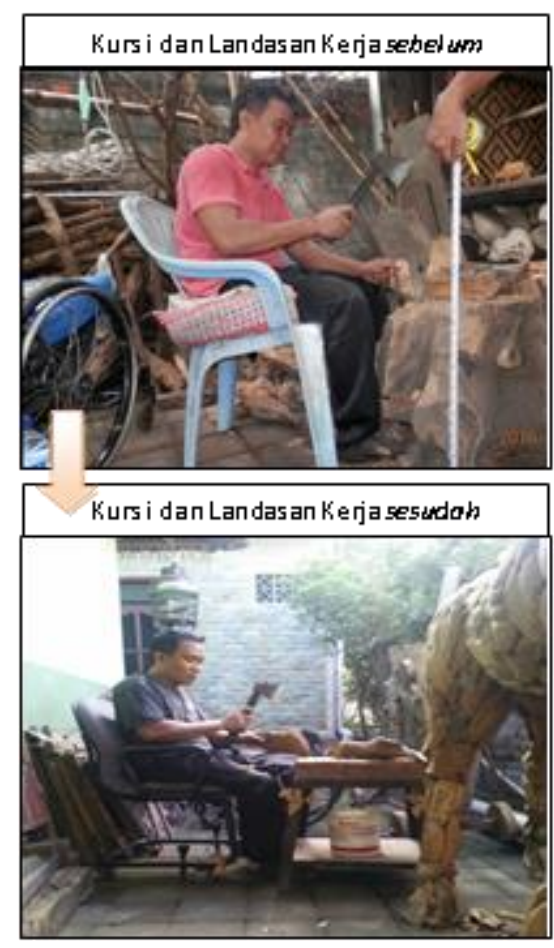

Gambar 3. Kursi dan landasar kerja

\section{B. Pembahasan}

Antropometri memang sangat diperlukan untuk menyesuaikan antara alat atau ruang kerja dengan orang yang bekerja atau beraktivitas di tempat tersebut, sebab seandainya ini tidak dipenuhi maka akan menimbulkan: ketidaknyamanan dalam beraktivitas, kelelahan lebih cepat muncul, risiko terjadinya kesalahan dalam beraktivitas lebih tinggi, beban kerja meningkat lebih cepat, energi yang diperlukan untuk usaha kerja yang sama ternyata lebih tinggi, sering menimbulkan gangguan otot terutama pada sistem muskuloskeletal, dan produktivitas menurun (Grandjean, 2007). 
Khusus pengrajin Kubu Shop yang mempunyai kebutuhan khusus semua peralatan dirancang sesuai antropometri pengrajin seperti kursi landasan kerja, lingkungan kerja dan peralatan kerja didesain khusus seperti pada gambar dibawah ini.

Rancangan mesin pemotong dan pembelah kayu yang ergonomis sesuai dengan antropometri yang ergonomis sesuai dengan antropometri pengrajin kebutuhan khusus.

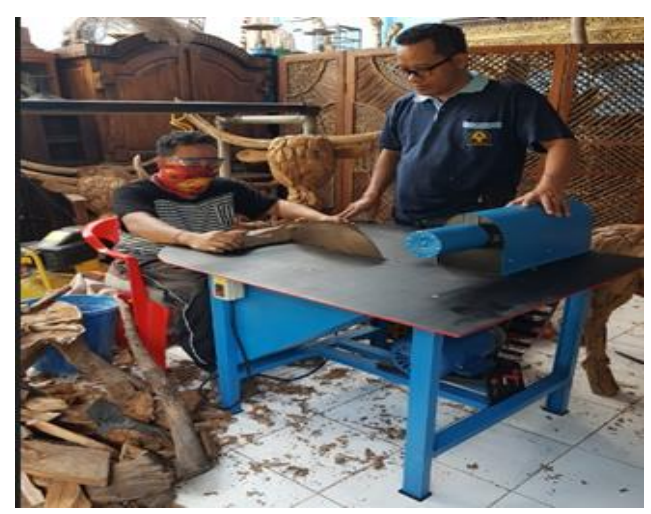

Gambar 4. Penggunaan mesin potong kayu

Proses pengerjaan sebuah produk kerajinan sudah menggunakan beberapa peralatan yang lebih moderen seperti ramset atau paku tembak menggunakan tekanan angin kompresor, untuk mempercepat proses perakitan bagian-bagian kerajinan seperti burung garuda (Gambar 5).

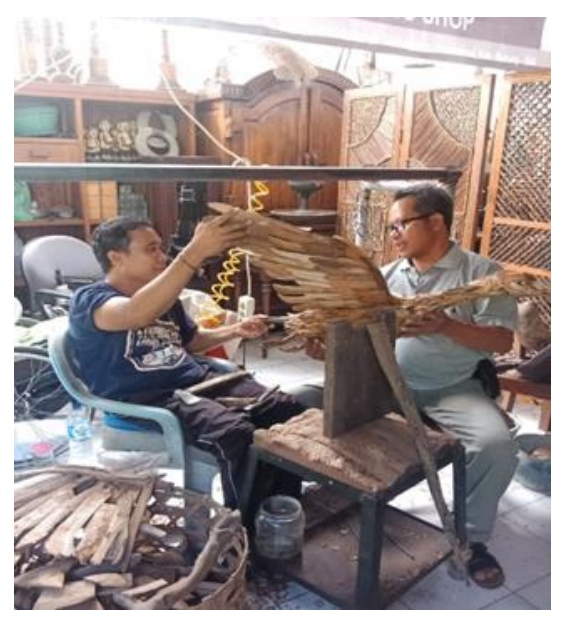

Gambar 5. Perakitan kerajinan burung garuda

Para pengrajin kayu bekas empasan pantai Ari Deco sedang membuat kerajinan meja, sudah menggunakan paku tembak atau ramset bertekanan menggunakan angin kompresor dan sudah menggunakan K3 seperti masker serta kaca mata pelindung. Seperti gambar dibawah ini.

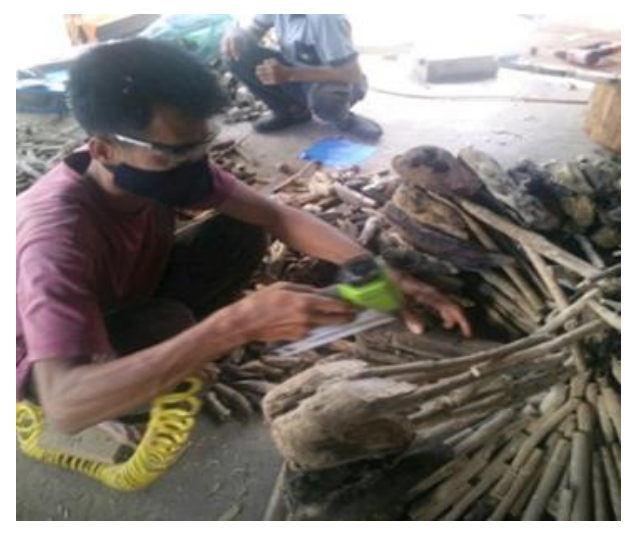

Gambar 6. Pembuatan meja

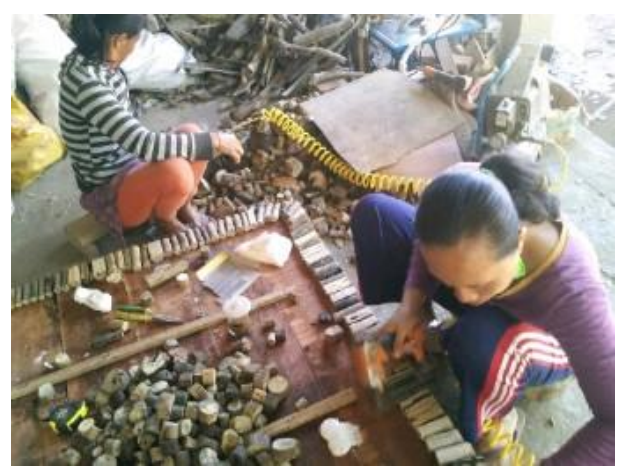

Gambar 7. Pembuatan pigura cermin

Pelatihan dan pendampingan mitra usaha dilaksanakan dengan metode FGD dari mitra pendamping seperti kargo dan dinas koperasi.

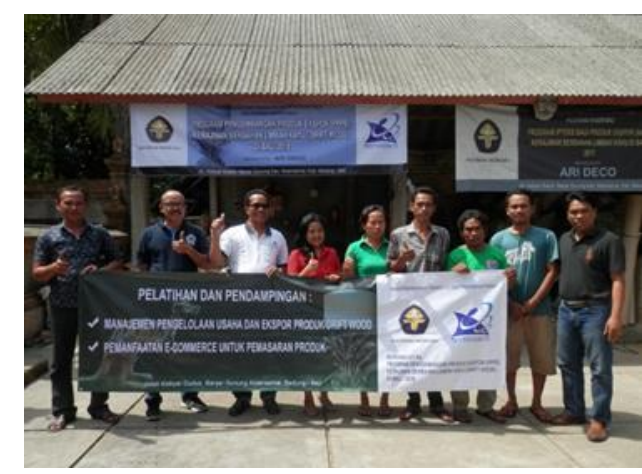

Gambar 8. Peserta pelatihan pemasaran 


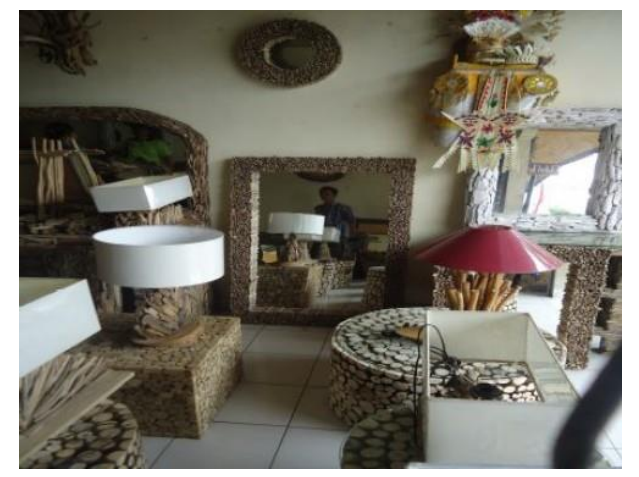

Gambar 9. Produk pigura cermin

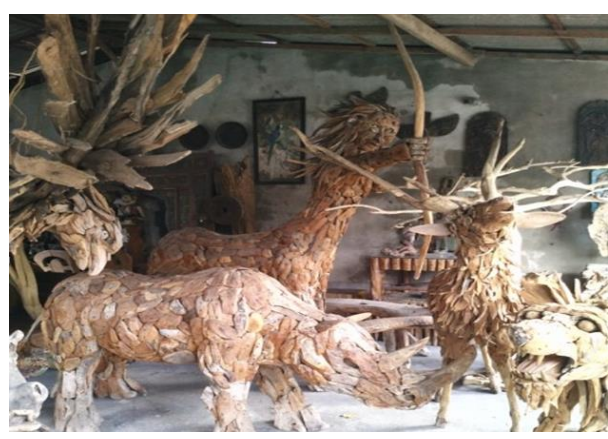

Gambar 10. Produk binatang

\section{KESIMPULAN}

Penerapan aplikasi ergonomi pada UKM di Ari Deco dan Kubu Shop mengalami perubahan yaitu penambahan peralatan dan urutan tata letak mesin serta peralatannya. Tata letak yang baik akan memberikan keluaran yang lebih besar dengan ongkos yang sama atau lebih sedikit, man hours yang lebih kecil, dan atau mengurangi jam kerja mesin. diharapkan mampu meningkatkan produksi dan produktifitas pengrajin/pekerja karena pekerja dapat bekerja dengan aman dan nyaman sehingga beban kerja menjadi lebih ringan.

Luaran yang telah dicapai adalah (1) Stasiun Kerja yang tertata dengan layout aliran material yang efesien di dukung dengan perkakas kerja yang memadai sehingga mampu mengoptimalkan capaian target produksi. (2) Perbaikan proses dan tata cara pelaksanaan penyelesaian pekerjaan. (3) Perbaikan dan penghematan penggunaan material, mesin, dan manusia. (4) Pendayagunaan usaha manusia. (5) Perbaikan tata ruang kerja yang mampu memberikan suasana lingkungan kerja yang nyaman dan aman. Penerapan ergonomi partisipatori kapasitas produksi dapat mencapai 456 buah/tahun dan produksi kubu shop sebanyak 24 buah/tahun misal binatang harimau, beruang, garuda, kepala sapi dll setelah dilakukan intervensi ergonomi meningkat menjadi 52 buah/tahun Dampak dari program ini adalah adanya peningkatan kapasitas produksi Ari Deco sebesar 67,5\% dan pengrajin Kubu Shop sebesar 46,15\% sedangkan omzet mitra usaha sekitar $69,9 \%$.

\section{DAFTAR PUSTAKA}

Disperindag-Badung. 2013. Perkembangan Pemasaran Ekspor Kerajinan di Kabupaten Badung.

Grandjean. 2007. Fitting the task to the human; a Textbook of Occupational Ergonomics. Fifth edition. Taylor \& Francis Publisher.

Purnomo. 2004. Perencanaan \& Perancangan Fasilitas. Yogyakarta: Graha Ilmu.

Sutalaksana. 2006. Pengautran Stasiun Kerja yang Ergonomis Guna Meningkatkan Kenyamanan Kerja.

Sedarmayanti. 2009. Sumber Daya Manusia dan Produktivitas Kerja. Bandung: CV. Mandar Maju. 